Brit. J. vener. Dis. (1966), 42, 145.

\title{
ISOLATION, CULTIVATION, LOW TEMPERATURE PRESERVATION, AND INFECTIVITY TITRATION OF TRICHOMONAS VAGINALIS*
}

BY

\author{
W. H. R. LUMSDEN, D. H. H. ROBERTSON, AND G. J. C. McNEILLAGE
}

From the Trypanosomiasis Research Unit, Royal (Dick) School of Veterinary Studies, University of Edinburgh, and the Department of Venereology, Royal Infirmary, Edinburgh

The diagnosis of Trichomonas vaginalis (Donné, 1837) infection by direct recognition of the parasite is comparatively easy in the acute phase in the female, more difficult in the male and in the female in the non-acute phase. Because of this difficulty conclusive epidemiological studies on $T$. vaginalis infection are few. Burch, Rees, and Reardon (1959) have contributed an informative study of the prevalence and transmission of $T$. vaginalis among groups of women in Washington, D.C., U.S.A., and their spouses, using culture for diagnosis. We considered that immunological studies might improve the diagnosis of $T$. vaginalis infection and facilitate studies on the epidemiology and clinical significance of this organism.

Kerr and Robertson, who published detailed immunological studies (conveniently summarized in Robertson, 1963, and Kerr, 1964) on Trichomonas foetus (Riedmuller, 1928) in the ox, established that the organism occurred as two different serological types. Kott and Adler (1961), by agglutination and agglutinin-absorption tests, distinguished eight different serotypes among nineteen strains of $T$. vaginalis and two among five strains of $T$. hominis (Davaine, 1860). They found, further, that two strains of $T$. vaginalis of different antigenic types changed, both to the same other type, after the cultures had been bacterially contaminated and then "cleaned" with antibiotics. Lindgren and Ivey (1964), assessing virulence by the results of intraperitoneal inoculation of mice, indicated that $T$. vaginalis strains might lose their virulence on prolonged serial passage in culture. They thought that virulence might be conserved by viable preservation of the organisms by freezing.

It appeared, therefore, that an essential preliminary to comparative immunological studies on

*Received for publication November 8, 1965.
$T$. vaginalis was the setting up of stabilates (Lumsden and Hardy, 1965, and vide infra) for reference purposes. Viable preservation of Trichomonas foetus for extended periods had already been accomplished by the storage of suspensions at low temperatures (e.g. by Levine, Anderson, Losch, Notzold, and Mehra, 1962) and this method appeared likely to be that most suitable for preparing stabilates of $T$. vaginalis.

Most workers (e.g. Levine and others, 1962) have used the proportion of organisms seen to be motile on retrieval from preservation as the index of the efficiency of the preservation method. Estimation of the proportion motile is clearly a useful index for this purpose, but it may not be an entirely reliable one. It is uncertain whether all organisms seen to be motile are capable of reproduction and also whether organisms seen not to be motile are necessarily incapable of reproduction. There was need of a measure of viability independent of any purely visual assessment; this could be supplied by experimental titration. Simple methods for the viable preservation of trypanosomes at low temperatures and for the titration of the infectivity to mice of trypanosome suspensions have been developed (Cunningham, Lumsden, and Webber, 1963; Lumsden, Cunningham, Webber, van Hoeve, and Walker 1963); the present paper reports the adaptation of these methods to Trichomonas vaginalis.

The formulae which have been proposed for culture media for Trichomonas spp. are many (Trussell, 1947; Feinberg and Whittington, 1957) and most are of complicated and unorganized constitution, which makes them difficult to manipulate experimentally when the effect of single factors is required to be isolated. Some work on the adaptation of the medium for experimental manipulation, preliminary to the main studies, is also reported. 


\section{Materials and Methods}

These were frequently subject to modification, following experimental results, during the course of the work. For the sake of brevity the procedures finally adopted will be described in this section, the experimental studies leading to their adoption later in the paper. Procedures in general followed the standard bacteriological technical methods described by Cruickshank (1962).

\section{Cultivation}

The medium used was derived from that described by Feinberg and Whittington (1957); its final constitution, and its method of preparation, are given below. Glassdistilled water and AnalaR reagents (British Drug Houses, Poole, Dorset) were used, except as otherwise stated.

$$
\begin{aligned}
& \text { (1) Salts Solution } \\
& \left.\begin{array}{llr}
\mathrm{NaCl} & 0 \cdot 154 \mathrm{M} & 100 \\
\mathrm{KCl} & 0 \cdot 154 \mathrm{M} & 4 \\
\mathrm{MgCl}_{2} & 0 \cdot 103 \mathrm{M} & 3 \\
\mathrm{CaCl}_{2} & 0 \cdot 103 \mathrm{M} & 1
\end{array}\right\} 108 \text { vols. }
\end{aligned}
$$

(2) Nutrients

Liver digest (Oxoid Division, Oxo, London: Code L 27; 40 gm. per l.) Dextrose $(0.308 \mathrm{M})$

$300.0 \mathrm{ml}$. $100.0 \mathrm{ml}$.

(3) Reducing Agent

Sodium thioglycollate (British Drug Houses: Laboratory Reagent)

$1.0 \mathrm{~g}$.

(4) Serum, Calf

(Oxoid Division, Oxo, London: Code SR 34)

$100 \cdot 0 \mathrm{ml}$.

(5) ANTiBiotics

Benzylpenicillin B.P. (Glaxo Laboratories, Greenford, Middlesex: Crystapen, 1 mega unit in $5 \mathrm{ml}$. salts solution as 1 , above)

Streptomycin sulphate (Glaxo Laboratories: $1 \mathrm{~g}$. (potency 745 units per mg.) in 5 mil. salts solution as 1 above)

$392 \cdot 5 \mathrm{ml}$.

6) Hydrogen-ion Concentration Control and INDICATOR

Buffer solution (pH 7.4) $\left.\begin{array}{lll}\mathrm{NaH}_{2} \mathrm{PO}_{4} & 0 \cdot 154 \mathrm{M} & 1.36 \\ \mathrm{Na}_{2} \mathrm{HPO}_{4} & 0.103 \mathrm{M} & 8.64\end{array}\right\} 10$ vols. $100 \cdot 0 \mathrm{ml}$.

Bromocresol purple (Hopkin and Williams, Chadwell Heath, Essex

$15 \mathrm{mg}$.

The salts and buffer solutions are prepared in bulk, autoclaved, and stored at $4^{\circ} \mathrm{C}$. To a mixture of them, in the volumes indicated, are added all the other ingredients and, after solution and mixing at room temperature, the whole medium is filtered through a sterile asbestos pad (Ford Sterimat Grade HP/S10) and distributed with sterile precaution, by automatic pipette (A. R. Horwell, Cricklewood, London), to screw-capped bottles in such quantities as nearly to fill them: $6 \mathrm{ml}$. to bijou bottles, $15 \mathrm{ml}$. to Loewenstein bottles. The screw-caps of the bottles are centrally perforated and fitted with white rubber wads to allow inoculation of the medium in the bottle without opening, by means of a syringe and needle through the wad. Bottles of medium are stored at $4^{\circ} \mathrm{C}$., unless for longer than 2 weeks, when they are stored at $-20^{\circ} \mathrm{C}$.

The final $\mathrm{pH}$ of the medium so prepared is $6 \cdot 1$ to $6 \cdot 4$; $\mathrm{pH}$ was measured by means of a direct-reading $\mathrm{pH}$ meter (Electronic Instruments Ltd., Richmond, Surrey, Model 23). Bromocresol purple changes colour from purple to yellow over a pH range of 6.8 to $5 \cdot 2$ (Diem, 1962) and thus indicates the $\mathrm{pH}$ change induced by the growth of T. vaginalis (Table I).

\section{TABLE I}

PROPAGATION OF $T$, VAGINALIS IN CULTURE MEDIA WITH VARIOUS CONCENTRATIONS OF LIVER DIGEST Each culture was inoculated with $T$, vaginalis from a 5-day-old culture (Strain A 96, passage 3) so that the initial concentration was antilog

\begin{tabular}{|c|c|c|c|c|c|}
\hline \multirow{2}{*}{$\begin{array}{c}\text { Liver Digest } \\
\text { Concentrations (g./1.) } \\
\text { in Culture } \\
\text { Medium }\end{array}$} & \multicolumn{4}{|c|}{$\begin{array}{l}\text { Concentrations of Organisms on } \\
\text { given day (log numbers per ml.) }\end{array}$} & \multirow{2}{*}{$\underset{6}{\mathrm{pH}}$} \\
\hline & 1 & 2 & 3 & 6 & \\
\hline $\begin{array}{r}0 \\
2.5 \\
5.8 \\
9 \cdot 2 \\
12.5 \\
15.8 \\
19.2 \\
22.5 \\
25.0\end{array}$ & \begin{tabular}{|c|}
$<3 \cdot 70$ \\
$<3 \cdot 70$ \\
$<3 \cdot 70$ \\
$4 \cdot 54^{*}$ \\
$4 \cdot 40^{*}$ \\
$4 \cdot 60^{*}$ \\
$4 \cdot 54^{*}$ \\
$4 \cdot 60^{*}$ \\
$4 \cdot 54^{*}$
\end{tabular} & $\begin{array}{l}4 \cdot 00 \dagger \\
4 \cdot 18 \dagger \\
4 \cdot 60^{*} \\
5 \cdot 14 \\
5 \cdot 23 \\
5 \cdot 30 \\
5 \cdot 24 \\
5 \cdot 31 \\
5 \cdot 20\end{array}$ & \begin{tabular}{|c|}
$<3.70$ \\
$<3.70$ \\
$4.00 \dagger$ \\
5.97 \\
5.91 \\
5.87 \\
5.83 \\
5.82 \\
5.79
\end{tabular} & $\begin{array}{l}4 \cdot 00 \dagger \\
4 \cdot 30 \dagger \\
4 \cdot 30 \dagger \\
6.08 \\
5.91 \\
6 \cdot 13 \\
5.92 \\
5 \cdot 96 \\
5 \cdot 93\end{array}$ & $\begin{array}{l}6 \cdot 6 \\
6 \cdot 4 \\
6 \cdot 3 \\
4 \cdot 5 \\
4 \cdot 5 \\
4 \cdot 5 \\
4 \cdot 5 \\
4 \cdot 5 \\
4 \cdot 5\end{array}$ \\
\hline
\end{tabular}
3.68 organisms per $\mathrm{ml}$.

* Standard errors $0 \cdot 11$ to $0 \cdot 30$ + Standard errors 0.31 to 0.60 .

\section{Isolation}

Isolations of $T$. vaginalis were made from patients attending the Royal Infirmary, Edinburgh, by inoculation of vaginal discharge into Loewenstein bottles containing medium. Isolations were made as follows:

$\begin{array}{ll}\text { Patient A 96 } & \text { April 24, 1964 } \\ \text { Patient A 112 } & \text { May 15, 1964 } \\ \text { Patient C 171 } & \text { February 6, 1964(A) } \\ & \text { March 2, 1964(B) } \\ \text { Patient C 3377 } & \text { May 26, 1964 } \\ \text { Patient C 3387 } & \text { June 8, 1964 }\end{array}$

\section{Passage}

Usually $0.1 \mathrm{ml}$. of the previous culture, shaken to suspend the organisms, was transferred by syringe and needle. Sometimes unmeasured inocula were transferred by Pasteur pipette. Passage was at 2- to 9-day, usually 5-day, intervals. Incubation was at $37^{\circ} \mathrm{C}$.

\section{Strains and Stabilates}

The term "strain" is used to indicate material maintained available by serial passage in culture (Lumsden and Hardy, 1965). Strains are designated according to the patients from which they were isolated.

The term "stabilate" is used as suggested by Lumsden and Hardy (1965) to indicate viably preserved material in which reproduction is arrested and selection (except for that associated with the process of preservation) thereby 
avoided. A stabilate can, therefore, be defined as a population of an organism preserved on a unique occasion. There are only as many examples of a stabilate as there are individual samples laid down on the unique occasion; each stabilate can be designated by a unique code number.

\section{Preparation of Stabilates}

The culture of organisms which it was desired to preserve was centrifuged at about $600 \mathrm{G}$ for 10 minutes. The supernate was removed by pipette and discarded and the deposited organisms resuspended in about $0.5 \mathrm{ml}$. of fresh medium. $0.2 \mathrm{ml}$. of this suspension was mixed with $0.8 \mathrm{ml}$. of 12.5 per cent. (v/v) dimethyl sulphoxide in fresh medium. The mixture containing 10 per cent. ( $\mathrm{v} / \mathrm{v})$ dimethyl sulphoxide (about 1.4 M), was then distributed with a Pasteur pipette to sterile lymph tubes (Plowden and Thompson, Stourbridge, England: "nominal $1 \mathrm{~mm}$. outside diameter, lymph tubes, 4 inches long") held in a rack as described by Cunningham and others (1963) (Figs 1 and 2).

The amount of suspension in each tube was about $20 \mu l$. The lymph tubes were then sealed at both ends in a

Fig. 1.-Lymph tubes, laid in notches of central channel of rack, held in place by a strip of metal faced with cotton wool and secured with adhesive tape. The rack is then enclosed between the upper and lower lids, wrapped in paper, and sterilized by autoclaving.

FIG . 2.-Filling suspension into lymph tubes.

Lower left: Test-tube containing lymph tubes in methanol in-

serted in insulating jacket for cooling.
Upper left: Zinc box with systematically-arranged, removable boxes, which, filled with methanol, are used for storing lymph tubes.
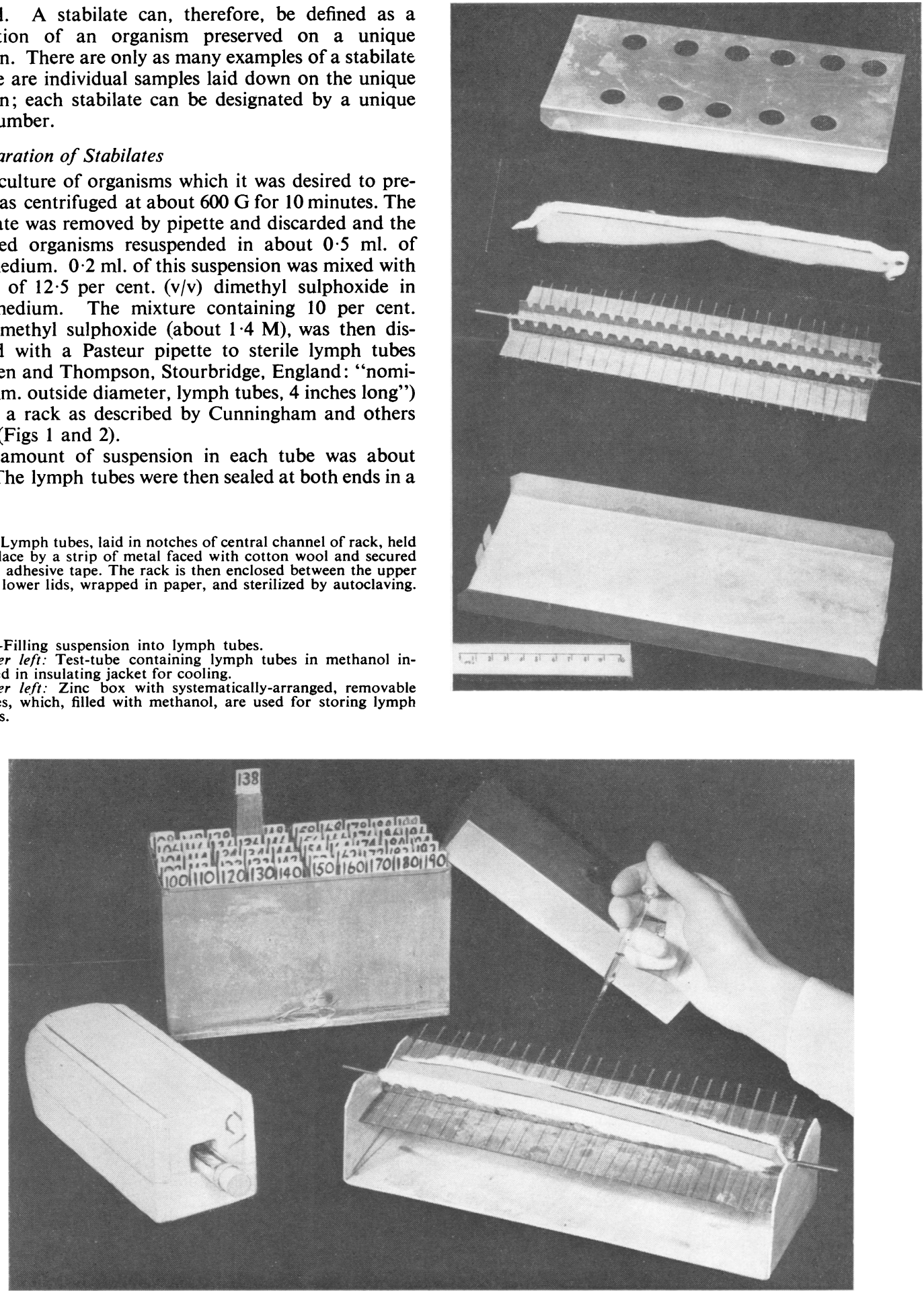
microburner, removed from the rack, and deposited in a test-tube $(15 \mathrm{~mm}$. diameter, $125 \mathrm{~mm}$. long) containing methanol at room temperature (Fig. 2). After corking, the test-tube was transferred to an insulating jacket of Onazote (Expanded Rubber and Plastics, Croydon, Surrey), of walls $25 \mathrm{~mm}$. thick (Fig. 2), which had been deposited several hours previously in the dry ice cabinet.

The rate of cooling of material treated in this way, as established by thermocouple, is shown in Fig. 3. After 24 hours in the jacket, the lymph tubes were transferred to the permanent storage unit (Fig. 2), by manipulation under methanol at $-79^{\circ} \mathrm{C}$ (Grainge, 1963).

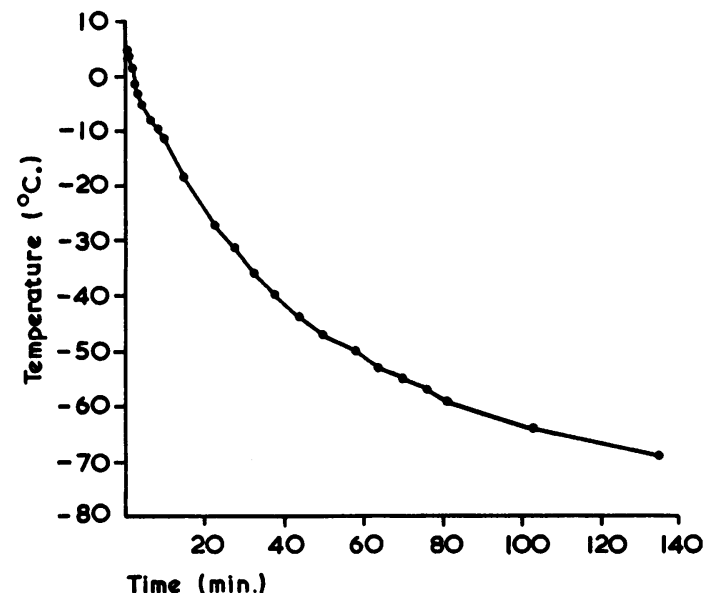

FIG. 3.-Cooling curve of $10 \mathrm{ml}$. volume of methanol in test-tube within insulating jacket of Onazote $(25 \mathrm{~mm}$. thick) in an ambient temperature of $-79^{\circ} \mathrm{C}$.

The following stabilates were studied:

TREU-44. Strain A 96, passed at 1-day interval, and preserved at passage 2 as a 5-day-old culture (April $30,1964)$.

TREU-47. Strain C 3377, passed at 1-day interval and preserved at passage $\mathbf{2}$ as a 2 -day-old culture (May $29,1964)$.

TREU-53. Derived from TREU-44; after 16 days' preservation and three further passages at 2- to 3-day intervals, preserved as a 3-day-old culture (May 23, 1964).

TREU-54. Strain A 112, passed at 2- to 3-day intervals and preserved at passage 3 as a 2 -day-old culture (May 23, 1964).

TREU-58. Strain C 171, passed at 1- to 4-day intervals, and preserved at passage 6 (TREU-27). After a period of preservation of 101 days, and three further passages at 3- to 4-day intervals, preserved as a 3-day-old culture (June 11, 1964).

TREU-59. Strain C 3387, passed at 1-day interval and preserved at passage 2 as a 2-day-old culture (June 11, 1964).

\section{Diluent}

A mixture of salts solution (see 1, Cultivation, above) 9 parts, and buffer solution (pH 5.8, see below, Adaptation of the medium) 1 part, was used.
Estimation of Concentration of $\mathrm{T}$. vaginalis in Suspension

The suspensions, if necessary diluted appropriately, were introduced into a haemacytometer (improved Neubauer ruling) and the organisms counted independently in two $1 \mathrm{~mm}$. squares, or in two $9 \mathrm{~mm} .^{2}$ areas, depending on the concentration of the organisms. Clumping of organisms sometimes gave difficulty in counting but usually clumps were small enough for the numbers of organisms composing them to be estimated. Means and their standard errors were calculated according to Dacie and Lewis (1963) and were expressed as $\log _{10}$ numbers of organisms per $\mathrm{ml}$. of the original suspension for direct comparison with infectivity estimates (see below). Standard errors of the estimates of numbers of organisms per ml. were almost always small in comparison to those of infectivity estimates; they have, therefore, usually been omitted except that cases in which they exceeded 0.10 in the $\log$ scale are noted. Where no organisms were seen, or only one, a limiting value is given.

\section{Estimation of Infectivity to Cultures of $\mathrm{T}$. vaginalis Suspensions}

The basis of the method for assaying the infectivity of suspensions of $T$. vaginalis was the same as that described by Lumsden and others (1963) for measuring the infectivity of trypanosome suspensions. The method, as applied to preserved stabilate material, is set out briefly below; for fresh suspensions, dilution may be, of course, by volumetric methods from the beginning.

The lymph tube containing the stabilate sample, after being removed from storage at $-79^{\circ} \mathrm{C}$., is allowed 30 seconds at room temperature to thaw, then dried with filter paper or cotton wool. Its sealed ends are cut off and the tube and its contents are weighed on a torsion balance (Griffin and George, Wembley, Middlesex: capacity $250 \mathrm{mg}$., in $0.5 \mathrm{mg}$. intervals) to the nearest $\mathrm{mg}$. The contents are expelled into $1.0 \mathrm{ml}$. of salts solution, buffered to $\mathrm{pH} \mathrm{6.0,} \mathrm{and} \mathrm{the} \mathrm{tube} \mathrm{re-weighed.} \mathrm{From} \mathrm{the}$ calculated weight of the suspension ejected, sufficient additional diluent is then added to give a 1 in 100 concentration $(w / v)$, called the $-2 \log$ dilution. The difference between the weight/volume and volume/volume ratio is neglected. Serial 10 -fold dilutions are then extended from the -2 log dilution as far as required by carrying over successively $\mathbf{0 . 2} \mathrm{ml}$. quantities of suspension into $1.8 \mathrm{ml}$. of diluent.

Polystyrene precipitin tubes (Luckham, Raynes Park, London: reference $L P / 2$ ), each containing $0.4 \mathrm{ml}$. of medium and covered with an aluminium foil cap, are set up in sets of six in polythene pockets (Fig. 4, opposite). A set is allocated to each of the dilutions which are to be tested for infectivity; $0.1 \mathrm{ml}$. of the dilution to be tested is inoculated to each tube of the set by means of a syringe and needle through the foil cap. The puncture in the foil is sealed with nail varnish (Northam Warren, London; Cutex). The inoculated tubes are incubated anaerobically at $37^{\circ} \mathrm{C}$. in a culture jar (Gallenkamp, Technico House, Sun Street, London: reference 


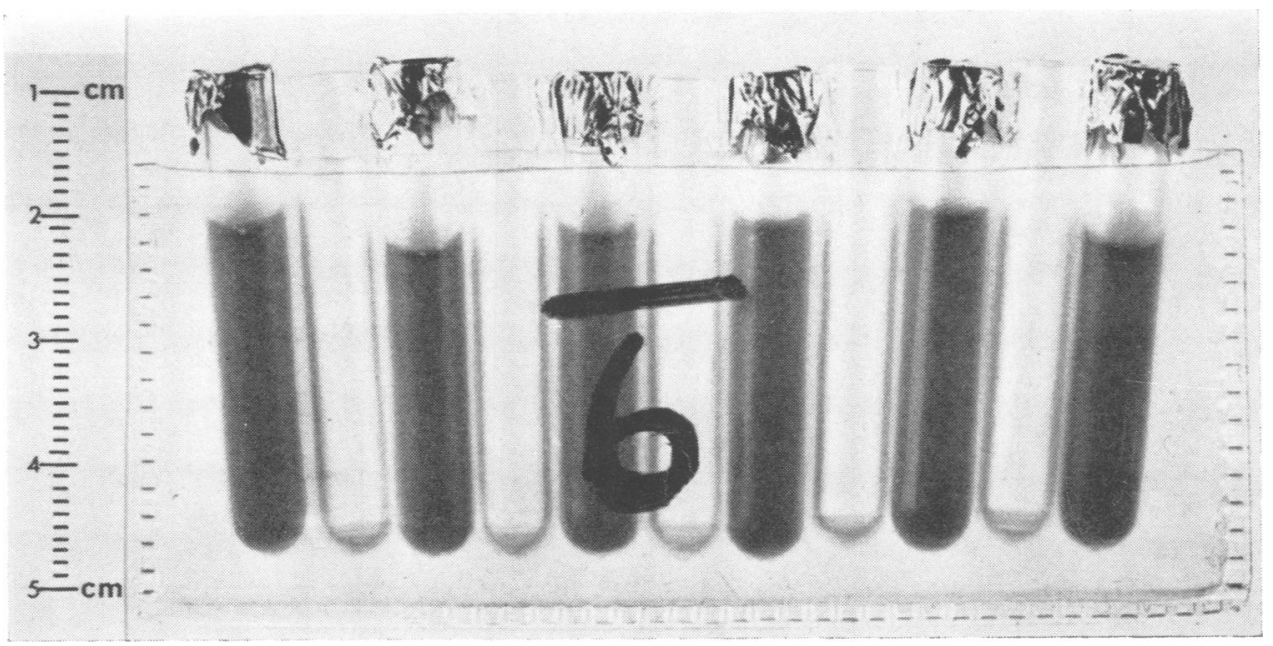

FIG. 4.-One of the sets of six polystyrene precipitin tubes, held in a polythene pocket, used for the titration of the infectivity to cultures of $T$. vaginalis suspensions.

CX-520) and examined for motile organisms on the sixth day. From the numbers of cultures becoming infected at each dilution, the infectivity of the original suspension is computed from the tables given by Lumsden and others (1963) and is expressed as the logarithm ${ }_{10}$ of the number of 63 per cent. infective doses $\left(\right.$ ID $_{63}$ ) per $\mathrm{ml}$. The 63 per cent. infective dose is that dose which infects 63 per cent. of the subjects inoculated with it. It represents a concentration of infective organisms such that the mean content of the inocula is one; at this concentration some recipients will receive one infective organism, some more than one, some none. The 63 per cent. infective dose is thus a measure of the infectivity of an organismal suspension directly comparable with estimates of the total concentration of organisms contained in it.

\section{Results}

\section{Adaptation of the Culture Medium}

The medium was basically that of Feinberg and Whittington (1957) modified to improve the ease with which the various characteristics of the medium could be adjusted for experimental purposes. The constituents were categorized according to their functional contribution to the medium and all major constituents were compounded as solutions nearly isotonic with blood plasma so that their individual representation might be altered without affecting the osmotic pressure of the medium as a whole. The isotonic concentration of the liver digest was determined by the observation of mouse erythrocytes suspended in various concentrations.
In order to improve control of the hydrogen-ion concentration of the medium the buffer capacities of its various components were investigated individually. The $\mathrm{pH}$ of individual solutions of each, of concentrations equal to those obtaining in the final medium (except in the case of the liver digest, which was investigated at the concentration originally recommended by Feinberg and Whittington (1957), 25 g. per 1.) was measured after successive additions of $0.2 \mathrm{ml}$. quantities of $0.05 \mathrm{~N} \mathrm{HCl}$ and $\mathrm{NaOH}$. The results of this experimentation are given in Fig. 5 (overleaf).

The salts solution was omitted from this study as it was known from earlier experience that it was negligibly buffered (Lumsden, Cunningham, Webber, van Hoeve, Knight, and Simmons, 1965). Fig. 5 shows that, of the other constituents of the medium, much buffer capacity resides only in the liver digest and in the serum solutions. The liver digest solution is particularly strongly buffered, at a $\mathrm{pH}$ of about $5 \cdot 1$. It was clear that the control of the hydrogen-ion concentration of the medium would be improved if the representation of this component could be reduced. Table I shows the results of an experiment to define the threshold concentration of liver digest necessary for the propagation of $T$. vaginalis. It propagates in a medium containing only $9 \cdot 2 \mathrm{~g}$. liver digest per litre as well as in those containing higher concentrations. The amount of liver digest solution was, accordingly, reduced in the final medium to give a concentration near this, $12 \cdot 0 \mathrm{~g}$. per litre. 


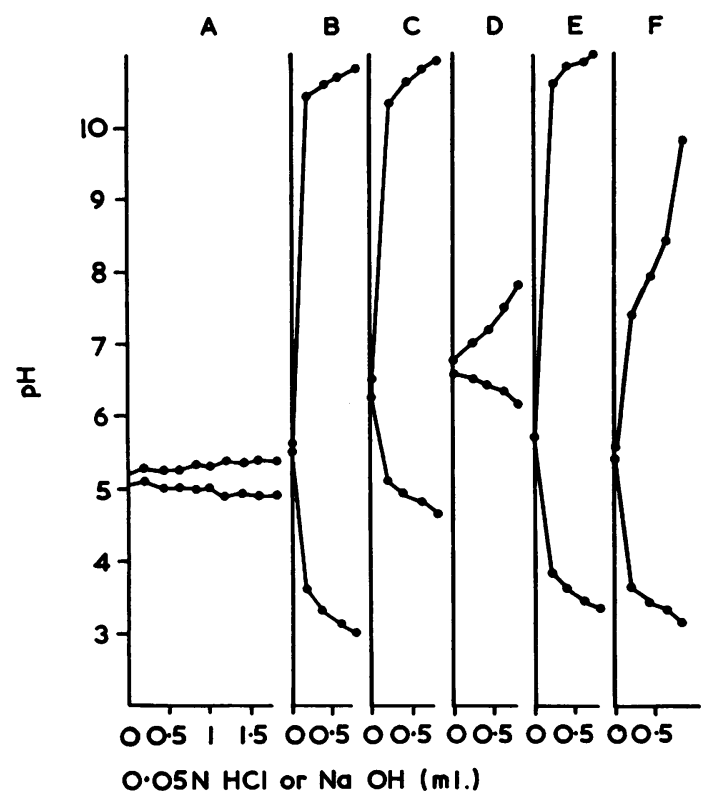

FIG. 5.-Buffer capacities of the various components of the culture medium; $\mathrm{pH}$ of solutions of (A) liver digest ( $25 \mathrm{~g}$./1.), (B) dextrose, (C) sodium thioglycollate, (D) serum, $(E)$ penicillin, and $(F)$ streptomycin (at the concentrations at which they are represented in the complete medium) after successive $0 \cdot 2-\mathrm{ml}$. additions of 0.05 $\mathrm{N} \mathrm{HCl}$ or $\mathrm{NaOH}$.

The reduction in the concentration of liver digest facilitated experimentation at a range of hydrogenion concentrations. For experiments at other $\mathrm{pH}$ values, the volume of the buffer component was doubled and its components adjusted as follows:

$\begin{array}{lrrr}\mathrm{NaH}_{2} \mathrm{PO}_{4} & 8.85 & 3.00 & 0.36 \\ \mathrm{Na}_{2} \mathrm{HPO}_{4} & \frac{1.15}{10.00} & \frac{7.00}{10.00} & \frac{9.64}{10.00} \text { volumes } \\ & \frac{1.8}{7.0} & \frac{8.0}{\text { pH }} & \frac{7.0}{2}\end{array}$

These modifications gave media of final $\mathrm{pH}$ values of, respectively, $5 \cdot 8,6 \cdot 8$, and $7 \cdot 6$. Table II shows the results of an experiment designed to compare three initial $\mathrm{pH}$ values for the culture medium for $T$. vaginalis. Of the three values investigated, $\mathrm{pH}$ 6.8 was the most favourable, although nearly as good growth was obtained at $\mathrm{pH} 5 \cdot 8$. The $\mathrm{pH}$ selected for the final medium, $\mathrm{pH} 6 \cdot 1$ to $6 \cdot 4$, is within this optimum zone.

\section{Preservation of $T$. vaginalis}

Preliminary experiments indicated that a few $T$. vaginalis individuals would survive as motile organisms in a 10 per cent. (v/v) solution of glycerol
TABLE II

PROPAGATION OF T. VAGINALIS IN MEDIA ADJUSTED TO pH $5 \cdot 8,6 \cdot 8$, AND $7 \cdot 6$, RESPECTIVELY

Each culture, two at each $\mathrm{pH}$, was inoculated with $T$. vaginalis from a 4-day-old culture (Strain A 96, passage 3) so that the initial concentration was antilog 3.98 organisms per $\mathrm{ml}$.

\begin{tabular}{|c|c|c|c|c|c|}
\hline \multirow{2}{*}{$\underset{\mathrm{pH}}{\text { Initial }}$} & \multirow{2}{*}{ Culture } & \multicolumn{4}{|c|}{$\begin{array}{l}\text { Concentration of Organisms on given day } \\
(\text { log numbers per } \mathrm{ml} .)\end{array}$} \\
\hline & & 1 & 2 & 3 & 4 \\
\hline \multirow{2}{*}{$5 \cdot 8$} & A & $<3 \cdot 70$ & $5 \cdot 18$ & $5 \cdot 80$ & $5 \cdot 79$ \\
\hline & B & $4 \cdot 17^{*}$ & $4 \cdot 81^{*}$ & $5 \cdot 54$ & $5 \cdot 81$ \\
\hline \multirow{2}{*}{$6 \cdot 8$} & $\mathbf{A}$ & $<3 \cdot 70$ & $5 \cdot 41$ & 6.06 & $6 \cdot 13$ \\
\hline & B & $4 \cdot 48$ & $5 \cdot 36$ & $6 \cdot 10$ & $6 \cdot 15$ \\
\hline \multirow{2}{*}{$7 \cdot 6$} & A & $4 \cdot 60^{*}$ & $4 \cdot 30^{*}$ & $5 \cdot 04$ & $5 \cdot 36$ \\
\hline & B & $<3 \cdot 70$ & $<3 \cdot 70$ & $<3 \cdot 70$ & $<3 \cdot 70$ \\
\hline
\end{tabular}

in culture medium for $\mathbf{2 0}$ or more hours, although most individuals became grossly distorted. Also, such suspensions, after slow cooling to $-79^{\circ} \mathrm{C}$., and thawing, were found to contain some motile organisms which could infect fresh cultures. It was clear, however, that a large mortality had taken place. It was considered that the criteria of a satisfactory process of preservation should be: that the morphology of the organisms should be substantially unaltered and that the survival rate, as judged by motility and by infectivity to cultures, should be at least 10 per cent. of the original population. To compare the results obtained with glycerol (Smith, 1961), dimethyl sulphoxide (Lovelock and Bishop, 1959; Ashwood-Smith, 1961) and polyvinyl pyrrolidone (Greaves, Nagington, and Kellaway, 1963) as freezing protectants, the experiment summarized in Table III (opposite) was performed.

A suspension of $T$. vaginalis was prepared by centrifuging two 5-day-old 12th-passage cultures of Strain C 171B to deposit the organisms and resuspending them in $1.0 \mathrm{ml}$. of fresh medium (Table III-original suspension). $0.2 \mathrm{ml}$. quantities of this suspension were added to $0.8 \mathrm{ml}$. quantities of 12.5 per cent. concentrations ( $\mathrm{v} / \mathrm{v}$ for glycerol and dimethyl sulphoxide, $\mathrm{w} / \mathrm{v}$ for polyvinyl pyrrolidone) of the substances whose effect was to be examined, giving 10 per cent. final concentrations, and to a control of medium. After mixing, the suspensions were distributed to lymph tubes (Cunningham and others, 1963) and groups of tubes were cooled, either rapidly or slowly, to $-79^{\circ} \mathrm{C}$. Rapid cooling was carried out by plunging the tubes individually into methanol at $-79^{\circ} \mathrm{C}$., slow cooling by the standard slow-cooling method described above. The numbers 
TABLE III

RESULTS OF SLOW- AND RAPID-COOLING PROCEDURES ON $T$. VAGINALIS WITHOUT FREEZING PROTECTANT AND WITH THE ADDITION OF GLYCEROL, DIMETHYL SULPHOXIDE, AND POLYVINYL PYRROLIDONE

Numerical values given are: logarithms of the numbers of organisms per ml.; the percentage motile of a sample of fifty organisms.

\begin{tabular}{|c|c|c|c|c|c|c|c|c|}
\hline $\begin{array}{c}\text { Original } \\
\text { Suspension }\end{array}$ & \multicolumn{8}{|c|}{$* 6 \cdot 70 ; 83$ per cent. } \\
\hline Substance added & \multicolumn{2}{|c|}{ None } & \multicolumn{2}{|c|}{$\begin{array}{c}\text { Glycerol } \\
(10 \text { per cent. } v / v)\end{array}$} & \multicolumn{2}{|c|}{$\begin{array}{l}\text { Dimethyl Sulphoxide } \\
(10 \text { per cent. v/v) }\end{array}$} & \multicolumn{2}{|c|}{$\begin{array}{l}\text { Polyvinyl Pyrrolidone } \\
(10 \text { per cent. } w / v)\end{array}$} \\
\hline $\begin{array}{ccc}\text { Stock } & \text { suspensions } & \text { after } \\
18-20 \mathrm{~min} . & . . & \ldots\end{array}$ & \multicolumn{2}{|c|}{$* 6.02 ; 84 \%$} & \multicolumn{2}{|c|}{$* 6.02 ; 2 \%$} & \multicolumn{2}{|c|}{$* 6 \cdot 10 ; 82 \%$} & \multicolumn{2}{|c|}{$* 6.01 ; 76 \%$} \\
\hline 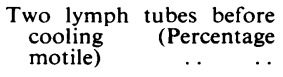 & \multicolumn{2}{|c|}{68,86} & \multicolumn{2}{|c|}{0,26} & \multicolumn{2}{|c|}{84,80} & \multicolumn{2}{|c|}{62,64} \\
\hline Rate of cooling & Fast & Slow & Fast & Slow & Fast & Slow & Fast & Slow \\
\hline $\begin{array}{c}\text { Two lymph tubes after } \\
24 \text { hrs at }-79^{\circ} \mathrm{C} .\end{array}$ & $\begin{array}{l}6.06 ; 0 \% \\
6.01 ; 0 \%\end{array}$ & $\begin{array}{l}6.07 ; 0 \% \\
5.94 ; 0 \%\end{array}$ & $\begin{array}{l}6.03 ; 0 \% \\
5.95 ; 0 \%\end{array}$ & $\begin{array}{l}5.99 ; 0 \% \\
5.99 ; 0 \%\end{array}$ & $\begin{array}{l}6.07 ; 0 \% \\
5.93 ; 0 \%\end{array}$ & $\begin{array}{l}5.99 ; 22 \% \\
6 \cdot 00 ; 26 \%\end{array}$ & $\begin{array}{ll}6 \cdot 08 ; & 0 \% \\
6 \cdot 26 ; & 0 \%\end{array}$ & $\begin{array}{ll}5 \cdot 98 ; & 0 \% \\
5 \cdot 99 ; & 0 \%\end{array}$ \\
\hline $\begin{array}{l}\text { Result of culture of inocu- } \\
\text { lum of contents of two } \\
\text { lymph tubes }\end{array}$ & - & + & - & + & - & + & - & - \\
\hline
\end{tabular}

* The original suspension was diluted 1 in 5 in the course of the preparation of each stock suspension, corresponding to a reduction in log concentration of organisms of $0 \cdot 70$.

of organisms and their percentage motility in the various suspensions through the course of the experiment are shown in Table III.

In 10 per cent. glycerol, most of the organisms became grossly distorted and few were motile, even immediately after mixing. Neither dimethyl sulphoxide nor polyvinyl pyrrolidone had any marked adverse effect on the numbers or motility of the organisms. Although numbers of organisms were undiminished after 24 hours storage at $-79^{\circ} \mathrm{C}$, after all the treatments, motile organisms were seen only after slow cooling in the presence of dimethyl sulphoxide. Inoculation of cultures, however, showed that some organisms had survived all the slow-cooling treatments, except that using polyvinyl pyrrolidone; none had survived any of the rapidcooling treatments.

The result with dimethyl sulphoxide and a slow rate of cooling, showing reductions in numbers of less than 0.2 on the $\log$ scale, and 22 per cent. motile after cooling to $-79^{\circ} \mathrm{C}$. for 24 hours, fulfilled the minimum criteria proposed for a satisfactory method. The results of the preparation of stabilates TREU-53 and TREU-54 offer additional evidence of the satisfactory nature of the method (Table IV). Both numbers and motility were well maintained in the process of preservation and over a period of storage of 85 days. Also, after this period of storage, when two lymph tubes of each stabilate were inoculated individually to cultures, all became infected.

Titration of the Infectivity of $T$. vaginalis Suspensions

First trials of the method of Lumsden and others (1963) for estimating the infectivity of $T$. vaginalis
TABLE IV

NUMBERS AND PERCENTAGES OF ORGANISMS MOTILE, IN SUSPENSIONS OF T. VAGINALIS AT VARIOUS STAGES IN THE PREPARATION AND STORAGE OF STABILATES TREU-53 AND TREU-54

\begin{tabular}{|c|c|c|}
\hline Stabilate & TREU-53 & TREU-54 \\
\hline $\begin{array}{l}\text { In } 10 \text { per cent. DMS solution } \\
\text { in culture medium before } \\
\text { distribution to lymph tubes }\end{array}$ & $6 \cdot 16 ; 100 \%$ & $6 \cdot 14 ; 100 \%$ \\
\hline $\begin{array}{c}\text { Two lymph tubes before } \\
\text { cooling } \ldots\end{array}$ & $\begin{array}{l}6 \cdot 02 ; 100 \% \\
6 \cdot 06 ; 100 \%\end{array}$ & $\begin{array}{l}6 \cdot 24 ; 100 \% \\
6 \cdot 08 ; 100 \%\end{array}$ \\
\hline $\begin{array}{c}\text { Two lymph tubes after } 24 \\
\text { hrs at }-79^{\circ} \mathrm{C} \text {. }\end{array}$ & $\begin{array}{l}6 \cdot 12 ; 70 \% \\
5 \cdot 98 ; 85 \%\end{array}$ & $\begin{array}{l}5.97 ; 75 \% \\
6.01 ; 85 \%\end{array}$ \\
\hline $\begin{array}{l}\text { One lymph tube after } 85 \\
\text { days' storage at }-79^{\circ} \mathrm{C} .\end{array}$ & $5 \cdot 99 ; \quad 85 \%$ & $5 \cdot 74 ; \quad 95 \%$ \\
\hline
\end{tabular}

suspensions were made, using small quantities of culture medium in various containers-2 $\mathrm{ml}$. ampoules closed with rubber cups or with cellophane, or precipitin tubes closed with cellophane-as recipients of the test inocula. These trials gave irregular results mostly indicating a very low level of infectivity, usually only about one organism in 1,000 or more. However, these trials indicated that the irregularity of the results might be related to inadequate control of the redox potential of the medium when it was dispensed in small containers not hermetically sealed. Accordingly, thereafter, the cultures were, after inoculation, incubated in anaerobic culture jars as described earlier in this paper.

Table V (overleaf) summarizes experiments done in this way. Estimates were made both of the concentrations of organisms in stabilates of $T$. vaginalis preserved for 61-100 days and of the infectivities of 
TABLE V

CONCENTRATIONS OF ORGANISMS AND INFECTIVITIES OF TWO SAMPLES EACH (A and B) OF FOUR T. VAGINALIS STABILATES STORED AT $-79^{\circ} \mathrm{C}$.

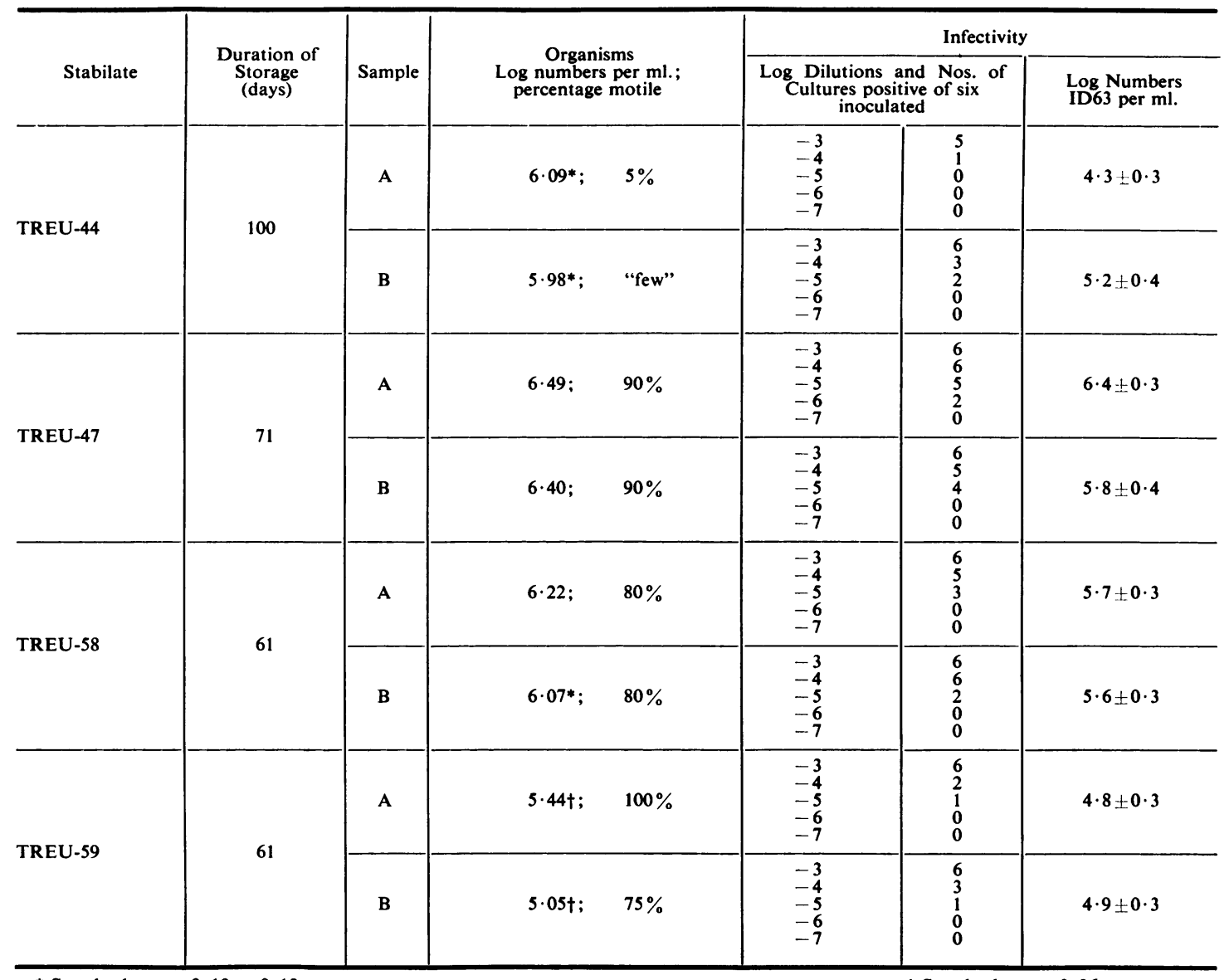

* Standard errors $0 \cdot 10$ to $0 \cdot 12$.

† Standard errors $0 \cdot 26$.

the stabilates. The difference between these two estimates was 1.8 on the log scale for one sample of TREU-44, indicating one organism in about sixty to be infective; otherwise the differences between the estimates were less than 0.8 on a log scale, indicating that doses of six organisms and less of these stabilates were sufficient to infect a culture (Lumsden and others, 1963). These results, taken in conjunction with those foregoing, which show the losses of numbers of organisms in the process of preservation to be small, show that the method developed for the preservation of $T$. vaginalis stabilates is a satisfactory one.

\section{Discussion}

Levine and Marquardt (1955), Levine, Mizell, and Houlahan (1958), Fitzgerald and Levine (1961),
Levine and Andersen (1961) and Levine and others (1962) investigated the preservation of Trichomonas foetus by freezing, judging the efficiency of their method mainly by observing the percentage of organisms which were motile after preservation. They obtained percentages of organisms motile as high as 38 per cent. after slow cooling of suspensions of organisms in culture medium in the presence of $1 \mathrm{M}$ glycerol and storing at $-95^{\circ} \mathrm{C}$. for 128 days. The present experimentation indicates that glycerol is an unsatisfactory freezing protectant for the preservation of $T$. vaginalis; the percentage of organisms motile was reduced to very low levels by the simple addition of 7.5 per cent. glycerol to the suspensions and no motile organisms were observed after cooling to $-79^{\circ} \mathrm{C}$. and retrieval, although some 
viable organisms survived as shown by the inoculation of culture.

Dimethyl sulphoxide has been used as an alternative to glycerol for the preservation of Trypanosoma and Plasmodium spp. and may be less toxic (Collins and Jeffery, 1963). From the present experimentation, dimethyl sulphoxide appears to be a more efficient freezing protectant than glycerol in the preservation of Trichomonas vaginalis; the concentrations of organisms in suspensions containing dimethyl sulphoxide show little loss from their original values in the process of preservation, and motile individuals composed generally 75 to 100 per cent. of the total numbers of organisms present. Further, suspensions preserved in this way have been shown by infectivity titration to have retained a high degree of infectivity to cultures; inocula of six organisms or fewer were sufficient to infect.

Establishment of methods for the setting up of stabilates of Trichomonas vaginalis and for titration of the infectivity to culture of $T$. vaginalis suspensions fulfil the two main first aims of the work and open the way to the development of quantitative studies on the effects of serum and other antibodies on $T$. vaginalis and for the study of the serological types of the parasite in relation to its clinical manifestations. In this connexion it is to be noted that some method other than that of the use of antibiotics may require to be found for the primary isolation of $T$. vaginalis; Kott and Adler (1961) found that "cleaning" bacteriologicallycontaminated strains with antibiotics was associated with a change in the antigenic type of organisms present in the strain.

A characteristic of $T$. vaginalis observed in the course of the present investigation, which appears to have some importance but to have escaped previous record, is the propensity of the organism to attach to surfaces. Neither the character of the surfaces to which the organisms attach nor the conditions under which attachment takes place have been investigated in detail, but it seems worth while to record that $T$. vaginalis has been observed attached to particles of glass and to fibres of unknown constitution occurring in the medium. It does not seem to attach to fibres of vegetable origin, such as cotton. Attached organisms may sometimes form a continuous carpet on the surface selected, reminiscent of the coating formed on intertidal rocks in temperate seas by the acorn barnacle, Balanus balanoides (L.). This tendency of $T$. vaginalis to attach to surfaces seems likely to be important in relation to the pathogenicity of the parasite and so would merit further study.

\section{Summary}

(1) The medium of Feinberg and Whittington (1957) for $T$. vaginalis was examined with a view to improving the ease of manipulation of its characteristics for experimental purposes. The minimum concentration of its most strongly buffered constituent, liver digest, for the propagation of $T$. vaginalis, was defined. Reduction of this constituent to near this level improved $\mathrm{pH}$ control of the medium.

(2) The optimum initial $\mathrm{pH}$ of the medium for $T$. vaginalis was found to be in the range $5 \cdot 8$ to $6 \cdot 4$.

(3) Six isolations of $T$. vaginalis were made.

(4) Trials of various freezing protectants and of two rates of cooling indicated slow cooling to $-79^{\circ} \mathrm{C}$. in the presence of dimethyl sulphoxide to be an efficient method for the preparation and preservation of stabilates of Trichomonas vaginalis, as judged by estimates of concentrations of organisms and proportions of individuals seen to be motile.

(5) The need, as regards suspensions of parasitic protozoa in general, and of material preserved at low temperature in particular, for a measure of viability independent of any purely visual assessment, is emphasized. A method for the titration of the infectivity to cultures of suspensions of $T$. vaginalis is described; this involves serial 10-fold dilution of suspensions, and inoculation of groups of cultures with several dilutions.

(6) Titration of the infectivity of $T$. vaginalis stabilates, preserved as described, indicated that six or fewer organisms generally constituted a dose infective to cultures.

Acknowledgement is made of the support given to W.H.R.L. and G.J.C.McN. under Grants R 1450 and $R$ 1450A of the Ministry of Overseas Development (Trypanosomiasis Research at Edinburgh University) and to D.H.H.R. and W.H.R.L. by the Insole Scholarship of the British Medical Association. Most of the work was done in the Immunology Unit of the Department of Bacteriology, University of Edinburgh Medical School; the help given by Prof. R. Cruickshank and $\mathrm{Dr}$ D. M. Weir in making laboratory facilities available there is gratefully recognized. We are glad to acknowledge, also, the help given to us by $\mathrm{Dr} \mathrm{R}$. Lees and the Staff of the Department of Venereology, Royal Infirmary, Edinburgh. 


\section{REFERENCES}

Ashwood-Smith, M. J. (1961). J. Physiol. (Lond.), 155, $26 \mathrm{P}$.

Burch, T. A., Rees, C. W., and Reardon, L. V. (1959). Amer. J. trop. Med. Hyg., 8, 312.

Collins, W. E., and Jeffery, G. M. (1963). J. Parasit., 49, 524.

Cruickshank, R. (ed.) (1960). “Mackie and McCartney's Handbook of Bacteriology", 10th ed. Livingstone, Edinburgh.

Cunningham, M. P., Lumsden, W. H. R., and Webber, W. A. F. (1963). Exp. Parasit., 14, 280.

Dacie, J. V., and Lewis, S. M. (1963). "Practical Haematology", 3rd ed. Churchill, London.

Davaine, C. (1860). "Traité des entozoaires et des maladies vermineuses de l'homme et des animaux domestiques". Baillière, Paris. (Cited by Trussell, 1947).

Donné, A. (1837). C. R. Acad. Sci. (Paris), 4, 464. (Cited by Trussell, 1947).

Diem, K. (ed.) (1962). "Documenta Geigy. Scientific Tables", 6th ed. Geigy Pharmaceutical Co., Manchester.

Feinberg, J. G., and Whittington, M. J. (1957). J. clin. Path., 10, 327.

Fitzgerald, P. R., and Levine, N. D. (1961). J. Protozool., 8, 21 .

Grainge, E. B. (1963). "East African Trypanosomiasis Research Organization Report, 1962-63”, p. 11-12.

Greaves, R. I. N., Nagington, J., and Kellaway, T. D. (1963). Fed. Proc., 22, 90.

Kerr, W. R. (1964). "Immobilization and Agglutination of Trichomonas foetus", in "Symposium, Council for International Organizations of Medical Sciences", ed. J. F. Ackroyd, pp. 249-257. Blackwell Scientific Publications, Oxford.

Kott, H., and Adler, S. (1961). Trans. roy. Soc. trop. Med. Hyg., 55, 333 .

Levine, N. D., and Andersen, F. L. (1961). J. Protozool., 8, Suppl., p. 5.

- 2 , Losch, M. B., Notzold, R. A., and Mehra, K. N. (1962). Ibid., 9, 347.

— and Marquardt, W. C. (1955). Ibid., 2, 100.

—, Mizell, M., and Houlahan, D. A. (1958). Exp. Parasit., 7, 236.

Lindgren, R. D., and Ivey, M. H. (1964). J. Parasit., 50, 226.

Lovelock, J. E., and Bishop, M. W. H. (1959). Nature (Lond.), 183, 1894.

Lumsden, W. H. R., Cunningham, M. P., Webber, W. A. F., van Hoeve, K., Knight, R. H., and Simmons, V. (1965). Exp. Parasit., 16, 8.

- $,-\ldots, \cdots,-$, and Walker, P. J. (1963). Ibid., 14, 269.

--- and Hardy, G. J. C. (1965). Nature (Lond.), 205, 1032.
Robertson, M. (1963). "Antibody Response in Cattle to Infection with Trichomonas foetus", in "Immunity to Protozoa: A Symposium of the British Society for Immunology", ed. P. C. C. Garnham, A. E. Pierce, and I. Roitt, pp. 336-345. Blackwell Scientific Publications, Oxford.

Smith, A. U. (1961). "Biological Effects of Freezing and Supercooling;" (Monographs of the Physiological Society No. 9). Arnold, London.

Trussell, R. E. (1947). "Trichomonas Vaginalis and Trichomoniasis". Blackwell, Oxford.

L'isolement, la culture, la preservation à basse température du Trichomonas vaginalis et le titrage de l'infection causée par cette organisme

\section{RÉSUMÉ}

(1) Le milieu de culture de Feinberg et Whittington (1957) pour le $\boldsymbol{T}$. vaginalis a été examiné afin de faciliter la manipulation de ses caractéristiques pour les besoins expérimentaux. La concentration minima de son constituant plus fortement tamponné, le foie digéré, pour la propagation du $T$. vaginalis a été définie. La réduction de ce constituant jusqu'à ce niveau a amélioré le contrôle $\mathrm{pH}$ de ce milieu de culture.

(2) Le pH initial optimum de ce milieu de culture a été trouvé dans la gamme de 5,8 à 6,4.

(3) Six isolements du $T$. vaginalis ont été faits.

(4) Des essais de plusieurs protecteurs gelés et de deux taux de réfrigérations ont indiqué que la refrigération lente jusqu'à $-79^{\circ} \mathrm{C}$. en présence de diméthyle sulphoxide est une méthode efficace pour la préparation et la préservation des "stabilates" du Trichomonas vaginalis, à en juger par les estimations de concentration des organismes et la proportion des organismes en mouvement.

(5) La nécessité de mesurer la viabilité des suspensions des protozoaires parasitiques en général et du matériel préservé à basse température en particulier, indépendamment d'une estimation purement visuelle, est accentuée. Une méthode de titrage de l'infection causée par des cultures de suspensions de $T$. vaginalis est décrite, cette méthode a nécessité des séries de dilutions des suspensions au 10ème et l'inoculation des groupes de cultures à plusieurs dilutions.

(6) Le titrage de l'infection causée par les "stabilates" des $T$. vaginalis, préservés comme décrit, a indiqué que six ou moins d'organismes constituent généralement une dose suffisante pour causer l'infection des cultures. 